\title{
Evidence of enzyme-mediated transesterification of synthetic cannabinoids with ethanol: potential toxicological impact
}

\author{
Orapan Apirakkan ${ }^{1} \cdot$ Ivana Gavrilović c $^{1,2} \cdot$ Giuseppe Floresta $^{1,3} \cdot$ Cheyanne Pierre $^{1,2} \cdot$ Annelies Cannaert $^{4}$. \\ Christophe P. Stove ${ }^{4} \cdot$ Paul I. Dargan $^{5,6} \cdot$ David A. Cowan $^{1} \cdot$ Lewis Couchman $^{7} \cdot$ Vincenzo Abbate $^{1}$ (I)
}

Received: 21 May 2019 / Accepted: 2 July 2019 / Published online: 13 July 2019

(c) The Author(s) 2019

\begin{abstract}
Purpose Synthetic cannabinoids (SCs) represent a large proportion of novel psychoactive substances on the black market and have caused a number of deaths. Polydrug use including combination of SCs and ethanol could further complicate the toxicological impact. To the best of our knowledge, there have been no reports presenting evidence of transesterification between SCs and ethanol in vitro.

Methods The in vitro metabolism of the four carboxylate SCs PB-22, NPB-22, 5-fluoro-PB-22 (5F-PB-22), and 5-fluoroNPB-22 (5F-NPB-22) in the presence of ethanol using human liver microsomes with and without appropriate enzyme inhibitors was studied. Newly identified SC ethyl esters were chemically synthesised and fully characterised. The activity of these $\mathrm{SCs}$ and their ethanol transesterification products were assessed using cannabinoid receptor $\left(\mathrm{CB}_{1}\right.$ and $\left.\mathrm{CB}_{2}\right)$ activation assays. Results SCs/ethanol transesterification products were detected and studied using liquid chromatography-high-resolution mass spectrometry. We have shown that the SC ethyl ester formation is mediated by human carboxyl esterase enzymes. The ethyl esters exhibited a reduced activity for the CB receptors compared with their parent compounds.

Conclusions These novel ethyl esters may be useful additional markers of cannabinoid administration, and especially so if they prove to have longer half-lives than their parent compounds.
\end{abstract}

Keywords Carboxylate synthetic cannabinoids $\cdot$ In vitro drug metabolism · Transesterification $\cdot 5$ F-NPB-22 $\cdot$ Ethanol · Biomarkers

\section{Introduction}

The use of synthetic cannabinoid receptor agonists, or simply 'synthetic cannabinoids' (SCs), is a global toxicological conundrum. Their use appears to have escalated during

Electronic supplementary material The online version of this article (https://doi.org/10.1007/s11419-019-00491-0) contains supplementary material, which is available to authorized users.

Vincenzo Abbate

vincenzo.abbate@kcl.ac.uk

1 Department of Analytical, Environmental and Forensic Sciences, King's Forensics, King's College London, London SE1 9NH, UK

2 Department of Analytical, Environmental and Forensic Sciences, Drug Control Centre, King's Forensics, King's College London, London SE1 9NH, UK

3 Department of Drug Sciences, University of Catania, V.le A. Doria, 95125 Catania, Italy
2008-2015 [1] under the pretence that these compounds are 'safe' and 'legal' [2], and it is assumed that their use cannot easily be detected [3]. Although there has been a decline in seized SCs recently, many of the recent substances are highly potent and harmful [1]. Originally, these compounds, which circumvented drug legislation in many countries, were sold over-the-counter in so-called headshops and on the Internet as vividly branded products such as 'Spice' in

4 Laboratory of Toxicology, Department of Bioanalysis, Faculty of Pharmaceutical Sciences, Ghent University, Ottergemsesteenweg 460, 9000 Ghent, Belgium

5 Clinical Toxicology, Guy's and St Thomas' NHS Foundation Trust and King's Health Partners, London, UK

6 Clinical Toxicology, Faculty of Life Sciences and Medicine, King's College London, London, UK

7 Analytical Services International, St. George's University of London, Cranmer Terrace, London SW17 0RE, UK 
Europe and 'K2' in the United States. The weakness of the Misuse of Drugs Act [4] and incorporated schedules in the UK could not readily keep up with the rapidity of novel compounds reaching the market, but the more recent UK Psychoactive Substances Act (PSA) in 2016 [5] appears to be having an impact. While some data suggest that the use of novel psychoactive substances (NPS), including SCs, has decreased since the introduction of the PSA, other studies suggest little impact in the number of emergency department presentations, and their use remains prevalent and problematic [6]. As of the end of 2017, more than 670 NPS were monitored by the European Monitoring Centre for Drugs and Drug Addiction (EMCDDA), and 179 out of these were SCs [1]. In the UK, this is especially relevant in the prisoner population and amongst those facing homelessness $[3,7]$. Not only are the clinical features of acute SC toxicity difficult to identify and treat, particularly for the more recent third-generation SCs $[6,8,9]$, but the analysis of these compounds in bulk-drug seizures and in biological samples can also be challenging, even using the most modern analytical instrumentation. Analysis is complicated by (1) the sheer number of SCs that exist $[10,11]$, (2) their physicochemical diversity, (3) the frequent formation of multiple (pharmacologically active) metabolites [10, 12-14], (4) their (in)stability and chemical transformations when ingested via smoking (i.e., their pyrolysis products [15-18]), (5) their potency, which transpires to low concentrations in biological samples, and (6) the limited availability of reference materials. To aid the identification of SCs and their metabolites, in vitro models based on incubation with human liver microsomes (HLMs) and other enzyme fractions [19], coupled with in silico predictions, are commonly used to determine the most likely metabolic routes of 'new' SCs [20]. In silico models are also extremely useful at predicting the pharmacology and potential toxicology of SCs [21, 22]. Such literature resources are invaluable for building large screening libraries to maximise the chances of detecting toxicologically relevant SC use in samples.

However, in substance-using populations, polydrug use is common [23]. Considerations of drug-drug interactions with SCs are important clinically [24], but possible or unexpected biotransformation due to co-ingested compounds should also be considered. For example, transesterification of cocaine following concomitant use of ethanol and cocaine is well known to produce the pharmacologically active metabolite cocaethylene $[25,26]$. Similarly, transesterification has also been demonstrated for methylphenidate, resulting in the production of ethylphenidate (itself an NPS with misuse potential) [27]. These reactions are primarily catalysed by human carboxylesterases (hCES) in the liver, which participate in phase I metabolism of xenobiotics. Transesterification of PB-22 can also be observed as a thermal degradation artefact when detecting by gas chromatography-mass spectrometry
(GC-MS) in the presence of methanol or ethanol as a solvent [28].

There is increasing evidence confirming the use of SCs together with ethanol. A recent United Nations Office on Drugs and Crime (UNODC) report [29] highlighted ethanol as the third most frequent substance found in SC-related fatalities. In addition, ester-based SCs including 5F-PB-22 were detected, together with ethanol and other substances in postmortem cases [30, 31]. ADB-CHMINACA (also known as MAB-CHMINACA) and ethanol were both detected in a patient admitted to hospit [32]. A further case reported a fatal poisoning with the synthetic cannabinoid AB-CHMINACA and ethanol [33]. Finally, blood and urine ethanol concentrations were reported in three fatalities related to the use of 5F-ADB, 5F-PB-22 and AB-CHMINACA (5F$\mathrm{PB}-22=2.60$ and $3.58 \mathrm{~g} / \mathrm{kg}, \mathrm{AB}-\mathrm{CHMINACA}=1.45$ and $2.57 \mathrm{~g} / \mathrm{kg}, 5 \mathrm{~F}-\mathrm{ADB}=0.09$ and $0.12 \mathrm{~g} / \mathrm{kg}$ for blood and urine ethanol concentrations, respectively) [34]. It is apparent that the discovery of novel biomarkers of concomitant SC-ethanol consumption should facilitate the interpretation of such analytical investigations and may allow both extending the detection time and assisting in the understanding of the patterns of toxicity associated with such polydrug abuse.

In this study, we report in vitro evidence from HLM incubation experiments for the transesterification of four estercontaining SCs, namely PB-22, NPB-22, 5F-PB-22, and 5F-NPB-22 (Fig. 1), in the presence of ethanol, giving rise to a further group of potential new indicators of combined SC/ethanol use. These compounds were chosen because of the presence of a labile ester bond in their structures, making them amenable to the described chemical reaction, as well as their prevalence [35].

To evaluate whether the transesterification products might be more biologically active than the parent compounds, we used an activity-based cannabinoid receptor assay [36-38] to investigate the in vitro receptor activity of the ethyl esters formed by transesterification of ethanol with these SCs.

\section{Materials and methods}

\section{Chemicals and reagents}

PB-22, NPB-22, 5F-PB-22 and 5F-NPB-22 were kindly provided by TICTAC Communications (London, UK). Their identity and purity were confirmed by nuclear magnetic resonance (NMR) spectroscopy and high-performance liquid chromatography-ultraviolet spectroscopy (HPLC-UV) (\% purity $>90 \%$ ). Methanol, acetonitrile, formic acid (all LC-MS grade) were purchased from Fisher Scientific (Loughborough, UK). Trifluoroacetic acid (TFA), chloroform- $d\left(\mathrm{CDCl}_{3}\right.$, isotopic purity 99.8 atom $\left.\% \mathrm{D}\right)$ were from Sigma-Aldrich (Dorset, UK). Deionised water was purified 
Fig. 1 Chemical structures of 5F-NPB-22, NPB-22, PB-22 and 5F-PB-22 (top panel), their corresponding ethyl esters (middle panel) and their hydrolysis product (bottom panel). SCs synthetic cannabinoids
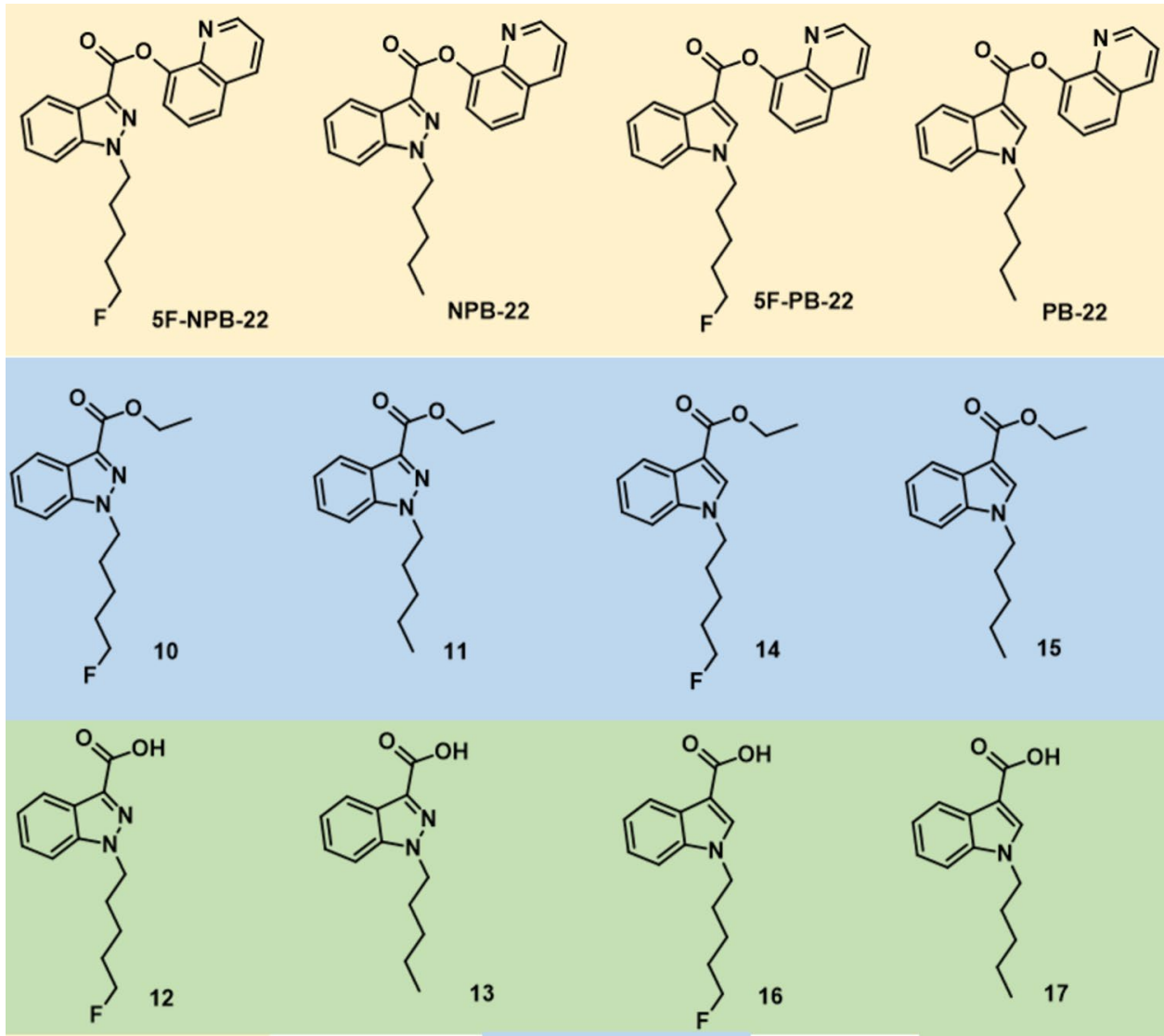

Parent SCs

SCs ethyl esters

SCs hydrolysed acid to $18.2 \mathrm{M} \Omega \mathrm{cm}$ resistivity using a PURELAB Ultra system (ELGA, Woodridge, UK). Aqueous phosphate buffer (0.5 mol/L, pH 7.4), pooled HLMs (150 donors), and reduced nicotinamide adenine dinucleotide phosphate (NADPH) regenerating system solutions A and B were purchased from Corning (Woburn, MA, USA); ethyl indazole3-carboxylate and 1-bromo-5-fluoropentane from FluoroChem (Hadfield, UK); 1,5-diiodopentane from Alfa Aesar (Lancashire, UK); ethyl indole-3-carboxylate and potassium tert-butoxide ( $t \mathrm{BuOK})$ from Aldrich (Dorset, $\mathrm{UK}$ ); potassium hydroxide $(\mathrm{KOH})$, bis- $p$-nitrophenylphosphate (BNPP), tetrahydrofuran (THF), hexane, ethyl acetate and ethanol from Sigma-Aldrich (St. Louis, MO, USA); anhydrous THF from Acros Organics (Geel, Belgium).

\section{Synthesis and characterisation of ethyl esters}

Synthesis of the ethyl esters (compounds 10, 11, 14 and 15, Fig. 1) was carried out via nucleophilic substitutions of the N1 nitrogen atoms of (1) ethyl indazole-3-carboxylate and (2) ethyl indole-3-carboxylate, each with 1,5-diiodopentane and 1-bromo-5-fluoropentane, to form the nonfluorinated and fluorinated analytes, respectively. Ester hydrolysis products (compounds 12, 13, 16 and 17, Fig. 1) were synthesised by alkaline hydrolysis of ethyl esters. Summary experimental data are given in supplementary material section S1. Ethyl esters were characterised using NMR $\left({ }^{1} \mathrm{H}-\mathrm{NMR},{ }^{13} \mathrm{C}-\mathrm{NMR}\right.$, homonuclear correlation spectroscopy-COSY, and heteronuclear single-quantum correlation spectroscopy-HSQC) (NMR, Bruker Avance DRX 400 MHz; Bruker BioSpin, Rheinstetten, Germany).

Further analysis was carried out using reversed-phase high-performance liquid chromatography with diode-array detection (HPLC-DAD, HP-1050) (Agilent Technologies, Santa Clara, CA, USA) using a $100 \times 2.1 \mathrm{~mm}$ i.d. C8 column (5 $\mu \mathrm{m}$, Kinetex ${ }^{\circledR}$; Phenomenex, Torrance, CA, USA). Solutions of each compound $[100 \mu \mathrm{g} / \mathrm{mL}$ in $0.1 \%(v / v)$ TFA in water] were eluted using a water/acetonitrile gradient (both containing $0.1 \%(v / v)$ TFA, ambient temperature, $31 \mathrm{~min}$ analysis time). Finally, solutions of each compound [300 ng/ $\mathrm{mL}$ in $10 \%(\mathrm{v} / \mathrm{v})$ acetonitrile in deionised water containing $0.3 \%(v / v)$ formic acid] were analysed by liquid chromatography-high-resolution mass spectrometry (LC-HRMS) to generate reference retention times and product ion $\left(\mathrm{MS}^{2}\right)$ spectra for the in vitro incubation experiments. 


\section{In vitro incubation}

The HLM method was based on that previously described [19]. Briefly, solutions containing $10 \mu \mathrm{g}$ of each substrate $(1 \mathrm{mg} / \mathrm{mL}, 10 \mu \mathrm{L})$ were added to Eppendorf LoBind ${ }^{\mathrm{TM}}$ tubes (Stevenage, UK), and evaporated to dryness. Buffer solution $(0.1 \mathrm{~mol} / \mathrm{L}$ aqueous phosphate buffer, $\mathrm{pH} 7.4$, $500 \mu \mathrm{L}$ ), NADPH-regenerating solutions [50 $\mu \mathrm{L}$ solution A: $26 \mathrm{mmol} / \mathrm{L} \mathrm{NADP}^{+}, 66 \mathrm{mmol} / \mathrm{L}$ glucose-6-phosphate, and $66 \mathrm{mmol} / \mathrm{L} \mathrm{MgCl}_{2}(\mathrm{aq}) ; 10 \mu \mathrm{L}$ solution $\mathrm{B}: 40 \mathrm{U} / \mathrm{mL}$ glucose-6-phosphate dehydrogenase in $5 \mathrm{mmol} / \mathrm{L}$ sodium citrate], and deionised water $(390 \mu \mathrm{L})$ were added. The tubes were capped, vortex-mixed, and preincubated $\left(37^{\circ} \mathrm{C}\right)$ with continuous gentle shaking for $10 \mathrm{~min}$ using an Eppendorf ThermoMixer ${ }^{\circledR}$ (Stevenage, UK). Reactions were initiated by the addition of HLM solution [protein content $20 \mathrm{mg} / \mathrm{mL}$ in $250 \mathrm{mmol} / \mathrm{L}$ sucrose $(\mathrm{aq}), 50 \mu \mathrm{L}$ ], gently mixed by hand and were incubated using an Eppendorf ThermoMixer ${ }^{\circledR}(2 \mathrm{~h}$, total reaction volume $1000 \mu \mathrm{L}$ ). A negative control was prepared by incubating each of the compounds with buffer solution and water, omitting the HLM and NADPH solutions. For incubations with ethanol, the initial volume of deionised water added to the incubation mixture was reduced to 340 $\mu \mathrm{L}$, and aqueous ethanol solution $[5.86 \%(v / v), 50 \mu \mathrm{L}]$ was added. The final concentration of ethanol was $50 \mathrm{mmol} / \mathrm{L}$ $(0.23 \mathrm{~g} / \mathrm{dL})$. In addition, incubations were carried out in the presence of specific carboxylesterase (CES), and nonspecific esterase inhibitors (BNPP and saturated NaF solution, respectively). For both experiments, the initial volume of deionised water added to the incubation mixture was reduced to $290 \mu \mathrm{L}$, and aqueous ethanol solution [5.86\% $(v / v), 50 \mu \mathrm{L}$ ] and inhibitor solution [either $1 \mathrm{mmol} / \mathrm{L}$ BNPP, or $10 \%(w / v)$ $\mathrm{NaF}$ in water, $50 \mu \mathrm{L}$ ] was added. The final concentration of ethanol was maintained at $50 \mathrm{mmol} / \mathrm{L}$.

After incubation, all reactions were quenched by the addition of ice-cold acetonitrile $(250 \mu \mathrm{L})$. Quenched solutions were vortex-mixed and centrifuged $(13,000 \mathrm{~g}, 15 \mathrm{~min})$. Supernatants were transferred to glass autosampler vials for analysis by LC-HRMS ( $5 \mu \mathrm{L}$ injection volume).

\section{LC-HRMS}

An UltiMate $3000^{\mathrm{TM}}$ HPLC system coupled to a Q Exactive $^{\mathrm{TM}}$ high-resolution mass spectrometer (both Thermo Scientific, San Jose, CA, USA) was used. Xcalibur ${ }^{\mathrm{TM}}$ software (version 14.0) was used for instrument control and data analysis. Chromatographic separation was performed using an Acquity ${ }^{\mathrm{TM}}$ BEH C18 column $(50 \times 2.1 \mathrm{~mm}$ i.d., $1.7 \mu \mathrm{m})$ (Waters, Borehamwood, UK). Eluents consisted of $0.3 \%(v / v)$ formic acid in deionised water (eluent A) and in acetonitrile (eluent B). Column temperature was maintained at $40{ }^{\circ} \mathrm{C}$. The elution gradient started at $10 \%$ eluent $\mathrm{B}$ (2 min), ramped to $95 \%$ (over $5 \mathrm{~min}$ ), and then decreased immediately to $10 \%$ (over $1 \mathrm{~min}$ ) prior to re-equilibration. The total analysis time was $10 \mathrm{~min}$.

Heated electrospray ionisation (HESI-II) settings were: sheath gas flow-rate 70; auxiliary gas flow-rate 10; spray voltage $3.75 \mathrm{kV}$; capillary temperature $320^{\circ} \mathrm{C}$; S-lens radio frequency level 55.0; auxiliary gas temperature $350^{\circ} \mathrm{C}$. Fullscan acquisition parameters were: positive ionisation mode; scan range $m / z, 100-1000$; resolution 70,000 full width at half maximum (FWHM); automatic gain control (AGC) target $1 \times 10^{6}$. $\mathrm{MS}^{2}$ acquisition parameters were: parallel reaction monitoring mode (based on an inclusion list containing the appropriate precursor ions); scan range $\mathrm{m} / \mathrm{z}$ 100-750; resolution 35,000 FWHM; AGC target $1 \times 10^{6}$. The isolation width was $1.2 \mathrm{amu}$. The normalised collision energy (NCE) was optimised manually using available standards and in-house synthesised products. For data review, total ion chromatograms were extracted using a $\pm 2.5 \mathrm{ppm}$ extraction window based on the exact $m / z$ values.

\section{Cannabinoid receptor assay}

To assess the biological activities of the compounds, live cell-based reporter assays that monitor protein-protein interactions via the NanoLuc Binary Technology were used. Here, the receptor activation is evaluated via the interaction between $\beta$-arrestin 2 ( $\beta$ arr2), a cytosolic protein, and the cannabinoid receptor $\mathrm{CB}_{1}$ or $\mathrm{CB}_{2}$. Both $\beta$ arr2 and $\mathrm{CB}_{1} /$ $\mathrm{CB}_{2}$ are fused to an inactive part of nanoluciferase. When $\mathrm{CB}_{1}$ or $\mathrm{CB}_{2}$ are activated by a ligand, $\beta$ arr2 is recruited to the receptor, allowing interaction of the complementary nanoluciferase subunits, yielding a functional enzyme that generates a bioluminescent signal in the presence of the substrate furimazine. Details regarding the development of the stable $\mathrm{CB}_{1}$ and $\mathrm{CB}_{2}$ cell lines used here have been reported elsewhere [36]. The original human embryonic kidney (HEK) T293 cell line was provided by Prof. O. De Wever (Laboratory of Experimental Cancer Research, Department of Radiation Oncology and Experimental Cancer Research, Ghent University Hospital, Belgium).

The cells were routinely maintained at $37{ }^{\circ} \mathrm{C}, 5 \% \mathrm{CO}_{2}$, under humidified atmosphere in Dulbecco's modified Eagle's medium (GlutaMAX ${ }^{\mathrm{TM}}$; Thermo Fisher Scientific, Waltham, MA, USA) supplemented with $10 \%$ heat-inactivated fetal bovine serum (FBS), $100 \mathrm{IU} / \mathrm{mL}$ penicillin, $100 \mathrm{mg} / \mathrm{L}$ streptomycin and $0.25 \mathrm{mg} / \mathrm{L}$ amphotericin B. Stability of the cell lines was followed by flow cytometric analysis. For experiments, cells were deposited on poly-D-lysine coated 96-well plates (Thermo Fisher Scientific) at $5 \times 10^{4}$ cells/well and incubated overnight. The cells were washed twice with OptiMEM $^{\circledR}$ I Reduced Serum Medium (Thermo Fisher Scientific) to remove any remaining FBS, and $100 \mu \mathrm{L}^{\text {Opti-MEM }}{ }^{\circledR}$ I was added. The Nano-Glo Live Cell reagent (Promega, Madison, WI, USA), a nonlytic detection reagent containing 
the cell permeable furimazine substrate, was prepared by 20-fold dilution of the Nano-Glo Live Cell substrate using Nano-Glo LCS Dilution buffer, and $25 \mu \mathrm{L}$ were added to each well. Subsequently, the plate was placed into a TriStar ${ }^{2}$ LB 942 multimode microplate reader (Berthold Technologies GmbH \& Co., Bad Wildbad, Germany). Luminescence was monitored during the equilibration period until the signal stabilised (15 min). We added $10 \mu \mathrm{L}$ per well of test compounds, present as concentrated (13.5-fold) stock solutions in 50\% $(v / v)$ methanol in Opti-MEM ${ }^{\circledR}$ I. The luminescence was continuously detected for $120 \mathrm{~min}$. Solvent controls were analysed with all experiments. The final concentration of methanol $(3.7 \% \mathrm{v} / \mathrm{v})$ has previously been verified to be well-tolerated by the cells [36].

Curve fitting and statistical analyses were performed using GraphPad Prism software (San Diego, CA, USA). The results are represented as mean area under the curve $(\mathrm{AUC}) \pm$ standard deviation $(\mathrm{SD})$ with at least five replicates for each data point (obtained in three independent experiments). All results were normalised to the $E_{\max }$ of JWH-018 $(=100 \%)$, our reference compound. Curve fitting of concentration-effect curves via nonlinear regression (four parameters logistic fit) was employed to determine $\mathrm{EC}_{50}$ (a measure of potency) and the $E_{\max }$ (a measure of efficacy). The maximal effect of all compounds was determined by either the $E_{\max }$ (for the parent compounds) or the maximal effect that was achieved for the compound at high concentrations.

\section{Results and discussion}

\section{Characterisation of compounds}

Data from the characterisation experiments (NMR and HPLC-UV) for the synthesised compounds (10-17) are presented in supplementary material section S1. Retention times, precursor ion $\mathrm{m} / z$ values $\left(\right.$ all $[\mathrm{M}+\mathrm{H}]^{+}$), and major product ion $\mathrm{m} / \mathrm{z}$ values for the parent compounds and the eight synthesised compounds generated using the LC-HRMS method are summarised in Table 1.

For the indoles PB-22 and 5F-PB-22, the characteristic major product ions observed were in agreement with previously published data [39], resulting from successive losses of the hydroxyquinolinyl substructures $(\mathrm{m} / \mathrm{z} 214.1228$ and 232.1121 for PB-22 and 5F-PB-22, respectively) and the (fluoro-) alkyl chains ( $\mathrm{m} / \mathrm{z} 144.0445$ and 144.0435 for both compounds).

Product ions spectra for the two indazoles, NPB-22 and 5F-NPB-22, showed analogous product ions $(\mathrm{m} / z 215.1183$ and 233.1074 for NPB-22 and 5F-NPB-22, respectively, plus 145.0398 and 145.0389 for both compounds). In addition, the indazoles gave rise to fragment ions corresponding to losses of the quinolinyl substructures, i.e., of the same $\mathrm{m} / \mathrm{z}$ as the precursor ions for compounds $\mathbf{1 3}$ and 12, the ester hydrolysis products $(\mathrm{m} / \mathrm{z} 233.1288$ and

Table 1 Summary LC-HRMS data for parent and synthesised compounds PB-22, NPB-22, 5F-PB-22, 5F-NPB-22, and metabolites 10-17

\begin{tabular}{|c|c|c|c|}
\hline Compound (formula) & RT (min) & $\begin{array}{l}\text { Precursor ion } \\
\text { accurate } m / z(\Delta \\
\mathrm{ppm})\end{array}$ & Major product ion(s) accurate $m / z(\Delta \mathrm{ppm})$ \\
\hline PB-22 $\left(\mathrm{C}_{23} \mathrm{H}_{22} \mathrm{~N}_{2} \mathrm{O}_{2}\right)$ & 6.21 & $359.1759(1.39)$ & $214.1228(0.93), 144.0445(0.69)$ \\
\hline NPB-22 $\left(\mathrm{C}_{22} \mathrm{H}_{21} \mathrm{~N}_{3} \mathrm{O}_{2}\right)$ & 6.29 & $360.1714(1.94)$ & 233.1288 (1.29), 215.1183 (1.86), 145.0398 (1.38) \\
\hline 5F-PB-22 $\left(\mathrm{C}_{23} \mathrm{H}_{21} \mathrm{~N}_{2} \mathrm{O}_{2} \mathrm{~F}\right)$ & 6.05 & $377.1652(-2.12)$ & $232.1121(-4.74), 144.0435(-6.25)$ \\
\hline 5F-NPB-22 $\left(\mathrm{C}_{22} \mathrm{H}_{20} \mathrm{~N}_{3} \mathrm{O}_{2} \mathrm{~F}\right)$ & 6.03 & $378.1603(-2.38)$ & $\begin{array}{l}251.1178(-4.78), 233.1074(-4.72), 213.1015(-3.28), \\
\quad 145.0389(-4.83)\end{array}$ \\
\hline PB-22 ethyl ester $(\mathbf{1 5})\left(\mathrm{C}_{16} \mathrm{H}_{21} \mathrm{NO}_{2}\right)$ & 6.52 & $260.1651(2.31)$ & $\begin{array}{l}232.1336(1.72), 214.1231(2.34), 188.1439(2.66), \\
132.0811(2.27), 118.0654(2.54)\end{array}$ \\
\hline NPB-22 ethyl ester $(\mathbf{1 1})\left(\mathrm{C}_{15} \mathrm{H}_{20} \mathrm{~N}_{2} \mathrm{O}_{2}\right)$ & 6.34 & $261.1598(0.00)$ & $233.1282(-1.29), 215.1178(-0.46), 145.0395(-0.70)$ \\
\hline 5F-PB-22 ethyl ester $(\mathbf{1 4})\left(\mathrm{C}_{16} \mathrm{H}_{20} \mathrm{NO}_{2} \mathrm{~F}\right)$ & 5.98 & $278.1556(1.80)$ & $\begin{array}{l}250.1241(1.20), 232.1136(1.72), 206.1345(2.43), \\
132.0811(2.27)\end{array}$ \\
\hline 5F-NPB-22 ethyl ester $(\mathbf{1 0})\left(\mathrm{C}_{15} \mathrm{H}_{19} \mathrm{~N}_{2} \mathrm{O}_{2} \mathrm{~F}\right)$ & 5.82 & $279.1503(0.00)$ & $\begin{array}{l}251.1188(-0.80), 233.1083(-0.86), 213.1021(-0.47), \\
\quad 145.0396(0.00)\end{array}$ \\
\hline PB-22 ester hydrolysis product (17) $\left(\mathrm{C}_{14} \mathrm{H}_{17} \mathrm{NO}_{2}\right)$ & 5.61 & $232.1334(0.86)$ & $\begin{array}{l}214.1225(-0.47), 188.1433(-0.53), 132.0807(-0.76), \\
\quad 118.0651(0.00)\end{array}$ \\
\hline NPB-22 ester hydrolysis product $(\mathbf{1 3})\left(\mathrm{C}_{13} \mathrm{H}_{16} \mathrm{~N}_{2} \mathrm{O}_{2}\right)$ & 5.21 & $233.1291(2.57)$ & 215.1183 (1.86), 163.0505 (1.84), 145.0399 (2.07) \\
\hline 5F-PB-22 ester hydrolysis product $(\mathbf{1 6})\left(\mathrm{C}_{14} \mathrm{H}_{16} \mathrm{NO}_{2} \mathrm{~F}\right)$ & 5.03 & $250.1244(2.40)$ & 232.1135 (1.29), 206.1344 (1.94), 132.0811 (2.27) \\
\hline $\begin{array}{l}\text { 5F-NPB-22 ester hydrolysis product (12) } \\
\left(\mathrm{C}_{13} \mathrm{H}_{15} \mathrm{~N}_{2} \mathrm{O}_{2} \mathrm{~F}\right)\end{array}$ & 4.85 & $251.1192(2.80)$ & $233.1084(-0.43), 213.1022(0.00), 145.0397$ (0.69) \\
\hline 5F-NPB-22 methyl ester $\left(\mathrm{C}_{14} \mathrm{H}_{17} \mathrm{~N}_{2} \mathrm{O}_{2} \mathrm{~F}\right)$ & 5.48 & $265.1354(2.64)$ & 251.1195 (1.99), 233.1089 (1.72), 213.1029 (3.28) \\
\hline
\end{tabular}

$L C-H R M S$ liquid chromatography-high-resolution mass spectrometry, $R T$ retention time 
251.1178 for NPB-22 and 5F-NPB-22, respectively). For 5F-NPB-22, a defluorinated product ion was also observed $(\mathrm{m} / \mathrm{z}, 213.1015)$ which was not observed in the case of 5F-PB-22.

For the ethyl ester and ester hydrolysis products of PB-22 (compounds 15 and 17), the major protonated carbonyl-indole core fragment ion $(\mathrm{m} / \mathrm{z}, 144.0444)$ was not observed at any significant relative abundance. Instead, the proposed alkyl-indole and alkyl-indole carboxylic acid product ions $(\mathrm{m} / \mathrm{z}, 188.1439$ and 232.1336 , respectively) were the major product ions for PB-22 ethyl ester, compound $\mathbf{1 5}$ (Fig. 2), in addition to a small amount of the ion at $m / z 214.1231$ also observed for both compounds $\mathbf{1 5}$ and 17. The ethyl ester of PB-22 gave rise to a product ion at $\mathrm{m} / \mathrm{z} 132.0811$ and 118.0654 , which were observed as major product ions of PB-22 ester hydrolysis, compound 17.

With respect to the ethyl esters and hydrolysis products of 5F-PB-22 (compounds $\mathbf{1 4}$ and 16), similar fragments as PB-22 ethyl ester and ester hydrolysis were observed. The major product ions were the alkyl-indole, $\mathrm{m} / \mathrm{z}$ 206.1337; and product ions at $m / z 250.1234,232.1129$ and 118.0650 being the fragments of alkyl-indole carboxylic acid, alkylindole carbaldehyde and indole group, respectively. The ethyl ester of 5F-PB-22 also gave rise to a product ion at $m / z, 132.0806$.

Observed product ions of NPB-22 ethyl ester and 5F-NPB-22 ethyl ester included the alkyl-indazole carboxylic acid, alkyl-indazole carbaldehyde, and indazole carbaldehyde $(\mathrm{m} / \mathrm{z}, 233.1276,215.1171$, and 145.0391 for NPB$22, \mathrm{~m} / \mathrm{z} 251.1187,233.1082$, and 145.0395 for 5F-NPB-22, respectively). The 5F-NPB-22 ethyl ester also yielded a defluorinated fragment ( $m / 2$ 213.1020) (Fig. 3) as observed in $\mathrm{MS}^{2}$ result of 5F-NPB-22 parent compound. The ester hydrolysis product ions of NPB-22 and 5F-NPB-22 gave similar results to those of their corresponding ethyl esters.

\section{HLM incubation experiments}

\section{PB-22 and 5F-PB-22}

In the absence of ethanol, metabolism of PB-22 proceeded as previously described to produce a series of phase I metabolites [39]. The major metabolite (by relative abundance) was the ester hydrolysis product (compound 17). Of note, this compound was also observed at a lower abundance (approximately 1\% of the parent compound) in the negative control samples, in which no HLMs were included in the incubation (see supplementary material S3.4). In addition to the ester hydrolysis product, a series of hydroxylated metabolites were observed, with characteristic $\mathrm{MS}^{2}$ fragments suggesting monohydroxylation on (1) the pentyl chain, (2) the indole core and (3) the quinolinyl substructure, carbonylation of the pentyl chain, and successive hydroxylation products following ester hydrolysis and $N$-dealkylation. When ethanol was present, in addition to these metabolites, the previously synthesised and characterised PB-22 ethyl ester was also detected along with further peaks suggesting monohydroxylation of the ethyl ester (Fig. 4). No ethyl ester was observed when PB-22 was incubated with ethanol in the presence of either saturated $\mathrm{NaF}$ (nonspecific CES inhibitor) or $1 \mathrm{mmol} / \mathrm{L}$ BNPP (specific CES inhibitor) (see supplementary material S3.2-S3.3). The observed LC-HRMS analyses and the $\mathrm{MS}^{2}$ spectra of ethyl esters when SCs were incubated with HLM and ethanol matched with the synthetic standards (see supplementary material S2.1-2.8 and S1.28-1.35).
Fig. 2 Product ion $\left(\mathrm{MS}^{2}\right)$ spectrum (annotated with proposed fragment ion structures) for the ethyl ester of PB-22 (compound 15 , exact $m / z$ for protonated molecular ion 260.1645) with normalised collision energy (NCE) at 25

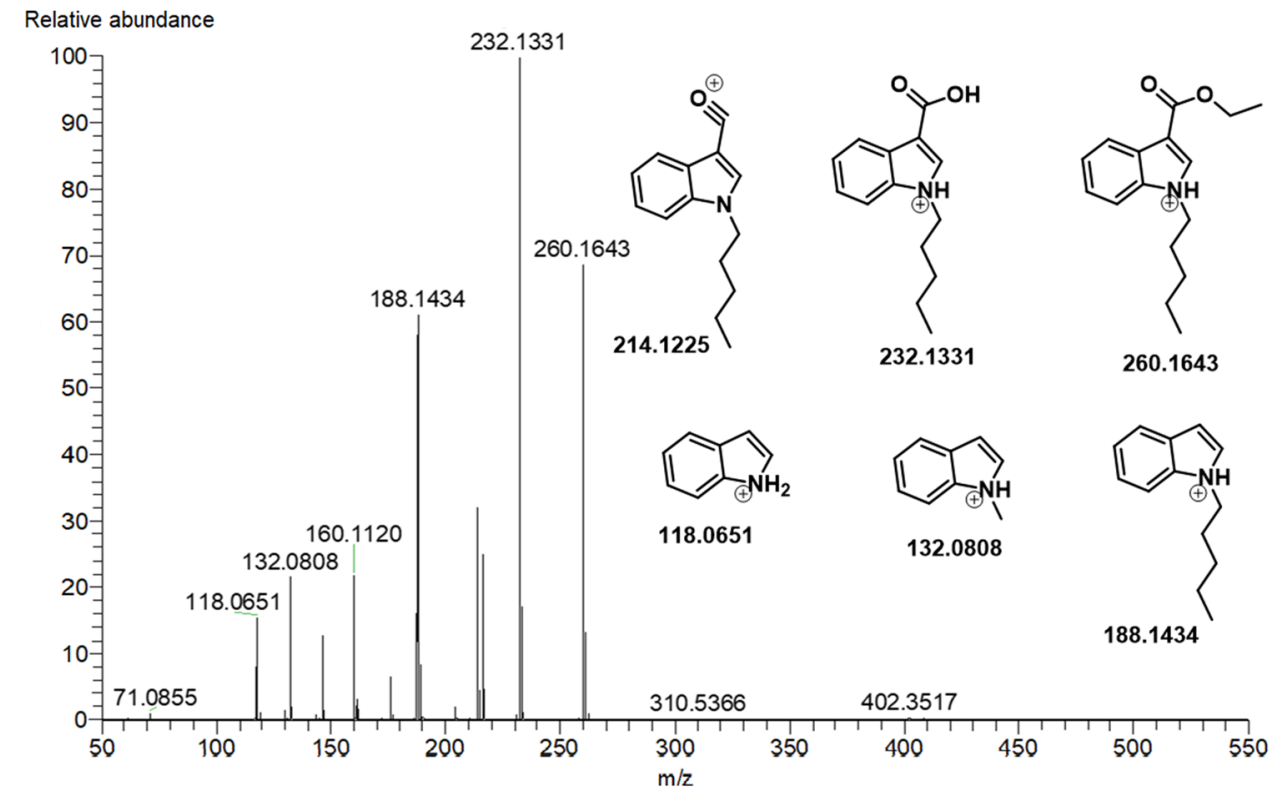


Fig. $3 \mathrm{MS}^{2}$ spectrum (annotated with proposed fragment ion structures) for the ethyl ester of 5F-NPB-22 (compound 10, exact $m / z$ for protonated molecular ion 279.1503) with $\mathrm{NCE}$ at 35

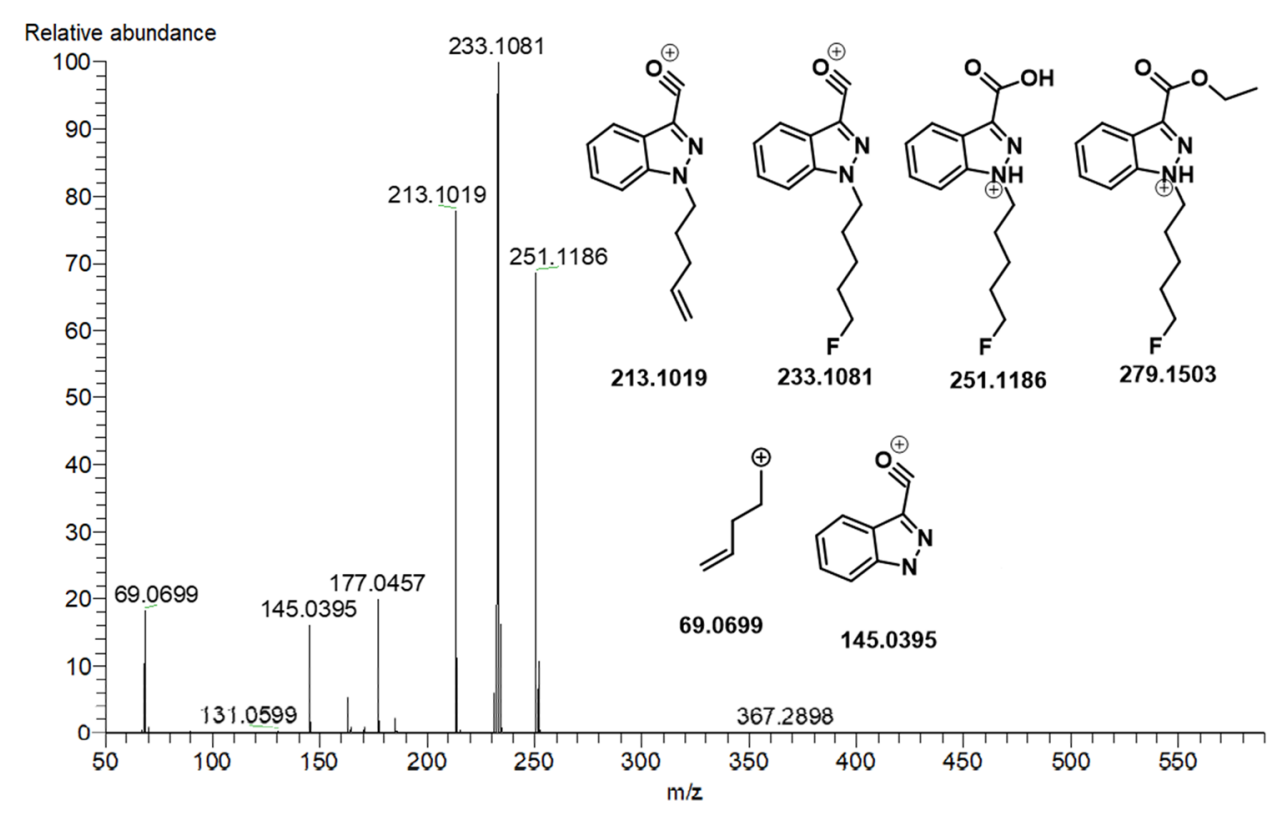

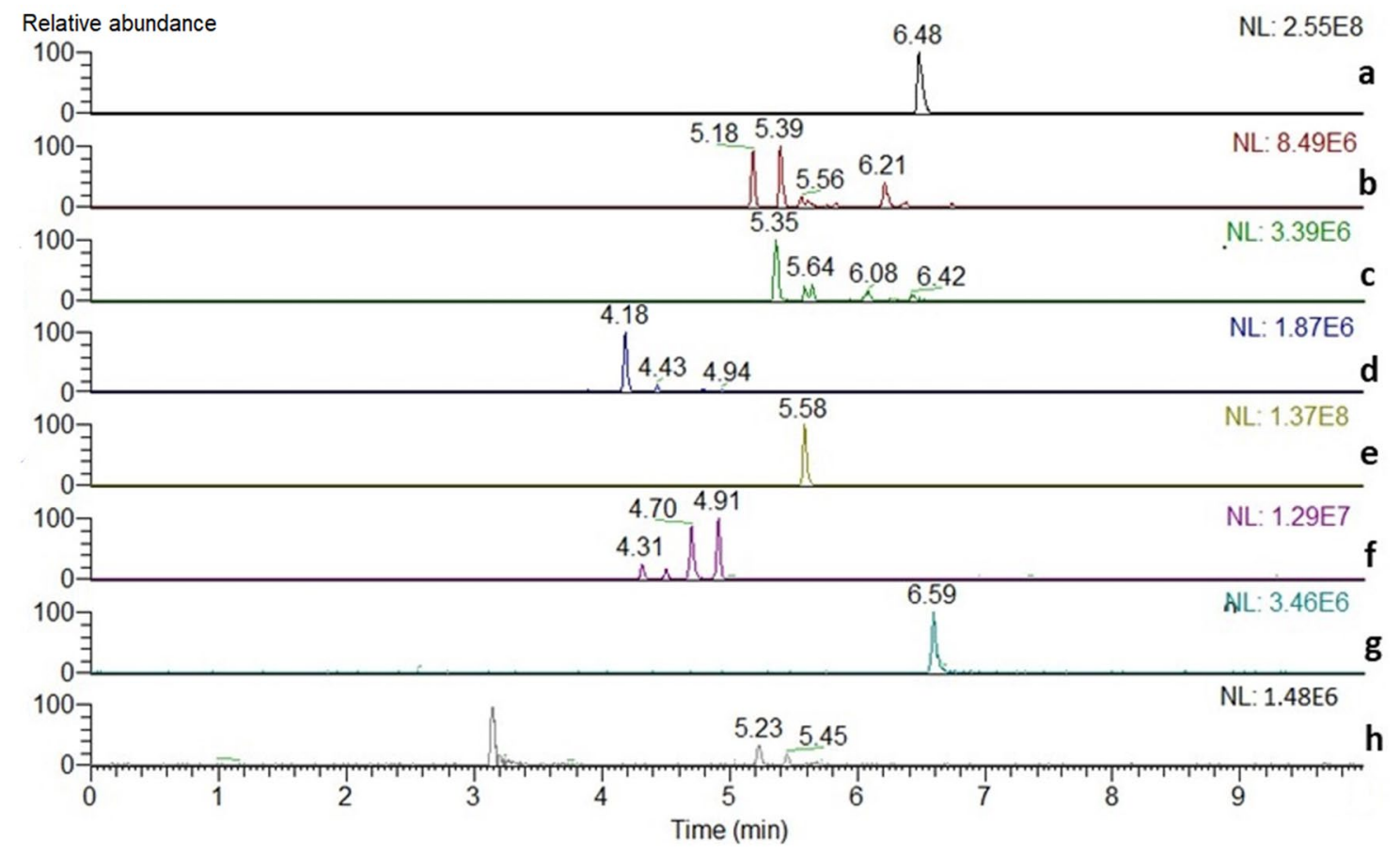

Fig. 4 Overlaid extracted ion chromatograms (exact mass $\pm 2.5 \mathrm{ppm}$ ) of the major detected PB-22 human liver microsome (HLM)-derived metabolites in the presence of ethanol: $\mathbf{a}=$ parent drug PB-22; $\mathbf{b}=$ monohydroxylation; $\mathbf{c}=$ carbonylation; $\mathbf{d}=$ monohydroxylation

A summary of the observed in vitro phase I metabolism, including transesterification in the presence of ethanol, for PB-22 is shown in Fig. 5.

For the fluorinated indole analogue 5F-PB-22, oxidative, reductive defluorination and oxidative defluorination to carboxylic acid products (see supplementary material with $N$-dealkylation; $\mathbf{e}=$ ester hydrolysis $(\mathbf{1 7}) ; \mathbf{f}=$ ester hydrolysis with monohydroxylation; $\mathbf{g}=$ PB-22 ethyl ester (15); $\mathbf{h}=$ PB-22 ethyl ester with monohydroxylation

S3.8) were observed in addition to the metabolites seen for PB-22. In the presence of ethanol, and ethanol plus CESinhibitor, similar results to its non-fluorinated analogue were observed.

These data demonstrate for the first-time evidence of hCES-mediated transesterification of selected 
Fig. 5 Proposed metabolic pathway for PB-22, inclusive of ethyl ester formation in the presence of ethanol. (a-h: refer to Fig. 4)

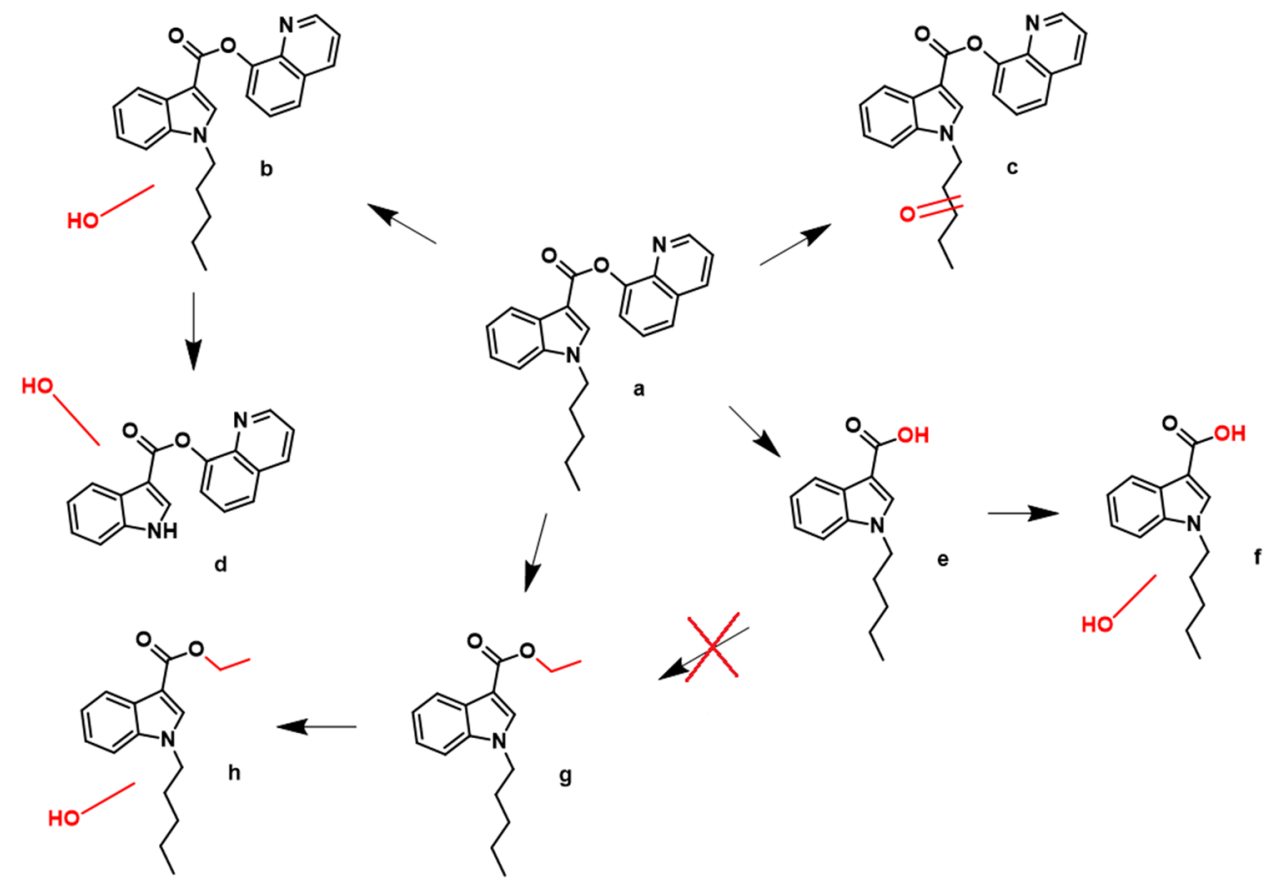

In the presence of ethanol, the ethyl esters of NPB-22 and 5F-NPB-22 were both detected. Interestingly, a small amount of the ethyl ester was observed (approximately $0.5 \%$ of the parent compound by abundance) in the presence of only buffer and ethanol (i.e., without any HLMs, see supplementary material S3.11 and S3.14). Indazole SCs clearly display more reactivity towards nucleophilic agents than their indole counterparts. Indeed, the NPB-22 family was more rapidly prone to hydrolysis, methanolysis and, therefore, ethanolysis (Fig. 8), even in the absence of any biocatalyst.

\section{Incubation of ester hydrolysis products with HLM}

To further elucidate the mechanism of formation of the newly detected SC ethyl esters, hydrolysed SC esters (compounds 12, 13, 16 and 17) were separately incubated with HLMs to monitor any ethyl ester product formation. This only yielded hydroxylated metabolites (data not shown). Incubation with HLMs and ethanol did not result in the formation of ethyl esters (illustrated in supplementary material S4). We concluded that the investigated biocatalysed reactions were highly dependent on the nature of the substrate: SC-ethanol transesterification occurred; however, esterification of the hydrolysed esters with ethanol was not observed. Indeed, hCES is well known to accommodate ester, thioester, carbamate, and amide bonds in its active site [40-42], suggesting that the hydrolysed esters, bearing a free carboxylic acid, are not good substrates for this enzyme family. 


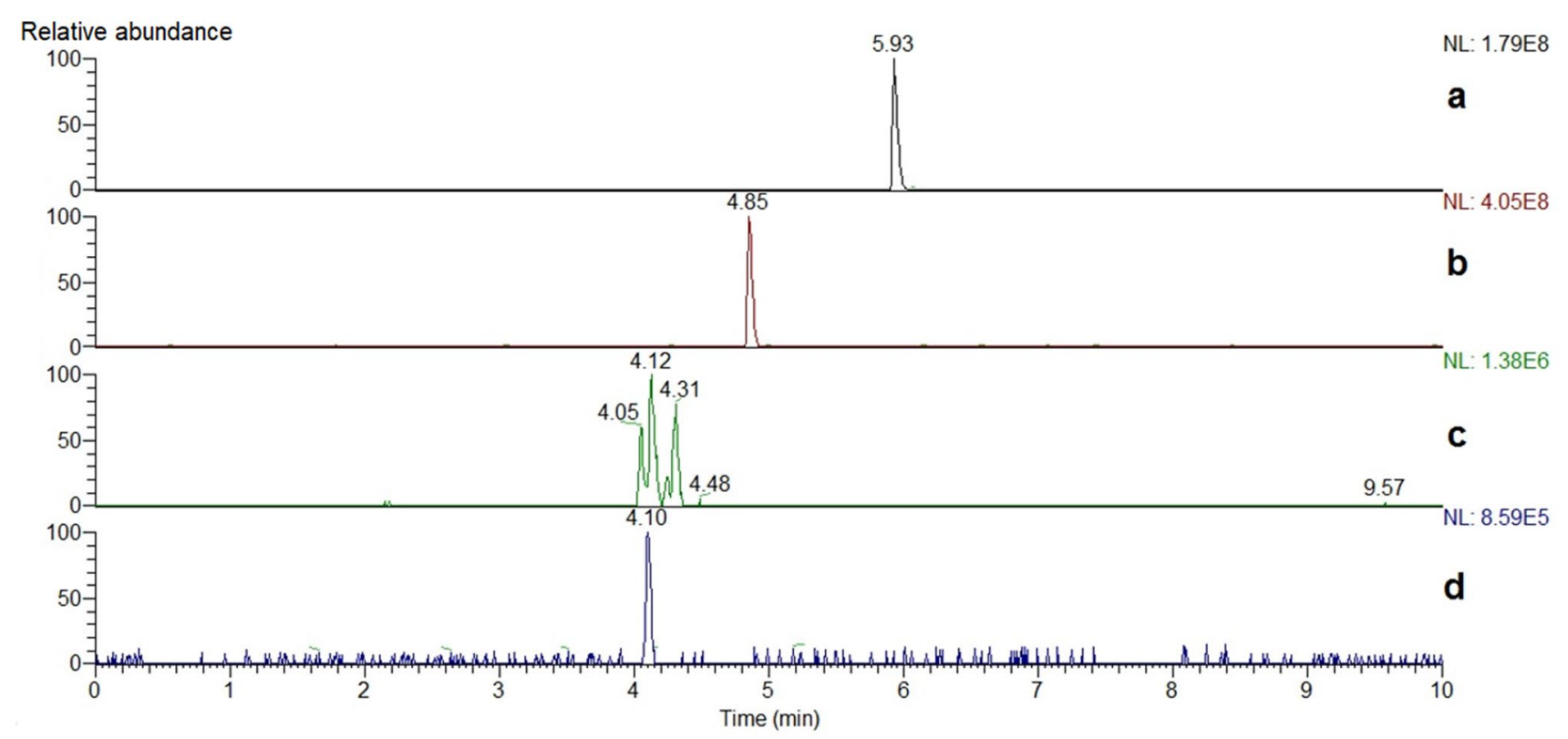

Fig. 6 Overlaid extracted ion chromatograms (exact mass $\pm 2.5 \mathrm{ppm}$ ) of 5F-NPB-22 HLM-derived metabolites (without ethanol): $\mathbf{a}=$ parent drug 5F-NPB-22; $\mathbf{b}=$ ester hydrolysis (12); $\mathbf{c}=$ ester hydrolysis with monohydroxylation; $\mathbf{d}=$ ester hydrolysis with oxidative defluorination

Fig. 7 Proposed metabolic pathways for 5F-NPB-22 (a-d refer to Fig. 6)<smiles>O=C(Oc1cccc2cccnc12)c1nn(CCCCCF)c2ccccc12</smiles>

Biological evaluation of PB-22, NPB-22, 5F-PB-22, 5F-NPB-22, their ethyl esters and their ester hydrolysis products

All parent compounds (PB-22, NPB-22, 5F-PB-22,
5F-NPB-22) showed a concentration dependent response in both the $\mathrm{CB}_{1}$ and $\mathrm{CB}_{2}$ receptor activation assays (Fig. 9). The $\mathrm{EC}_{50}$ and $E_{\max }$ values were determined as a measure of relative potency and efficacy, respectively (see supplementary material S5.1). Both the $\mathrm{EC}_{50}$ and $E_{\max }$ values of PB-22 


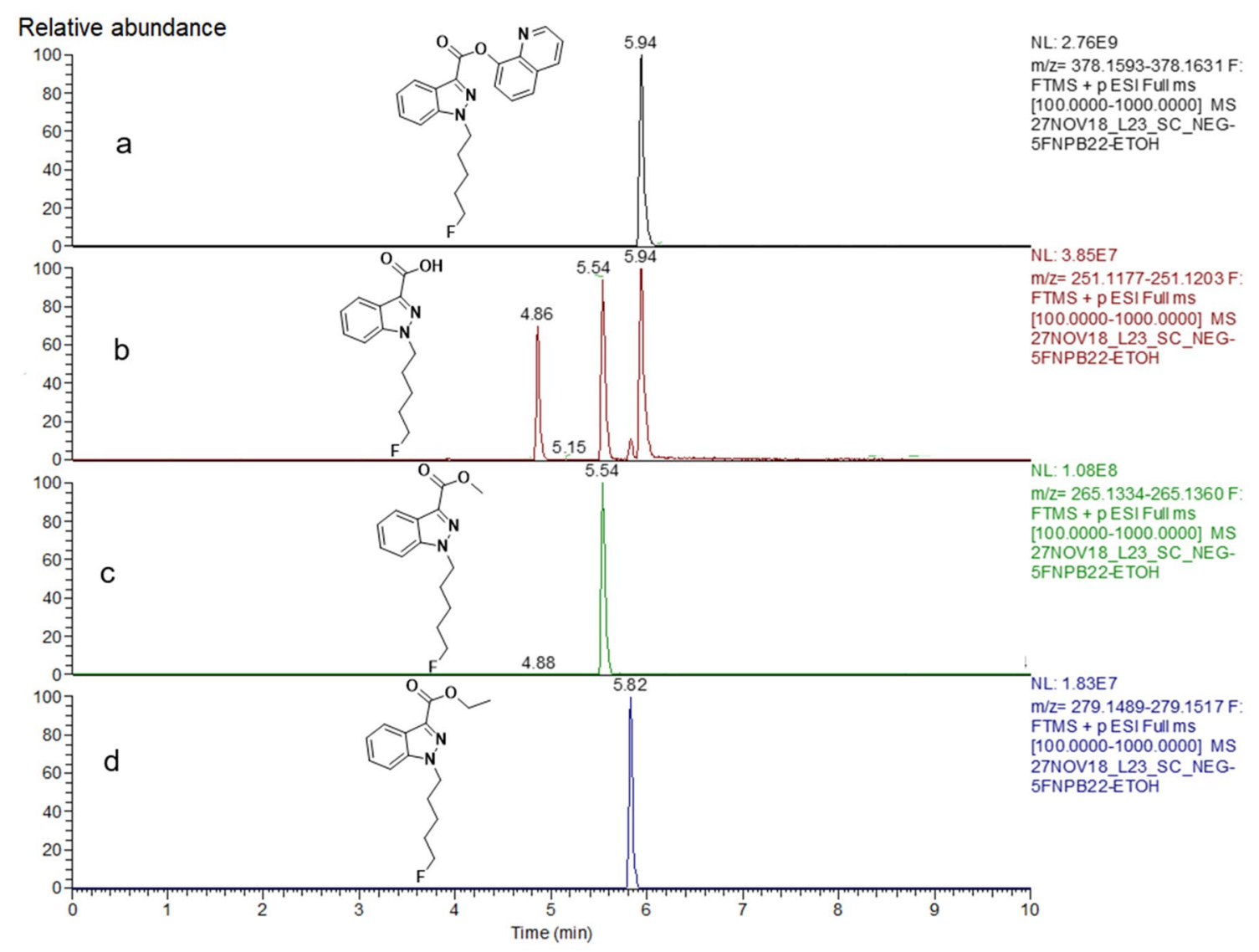

Fig. 8 Overlaid extracted ion chromatograms (exact mass $\pm 2.5 \mathrm{ppm}$ ) of 5F-NPB-22 in the presence of methanol and ethanol (without HLM); $\mathbf{a}=5 \mathrm{~F}-\mathrm{NPB}-22 ; \mathbf{b}=$ hydrolysis of $5 \mathrm{~F} \mathrm{NPB}-22 ; \mathbf{c}=$ methanolysis of $5 \mathrm{~F}-\mathrm{NPB}-22 ; \mathbf{d}=$ ethanolysis of $5 \mathrm{~F}-\mathrm{NPB}-22$

a $\quad \mathrm{CB}_{1}$ activation (relative to JWH-018)

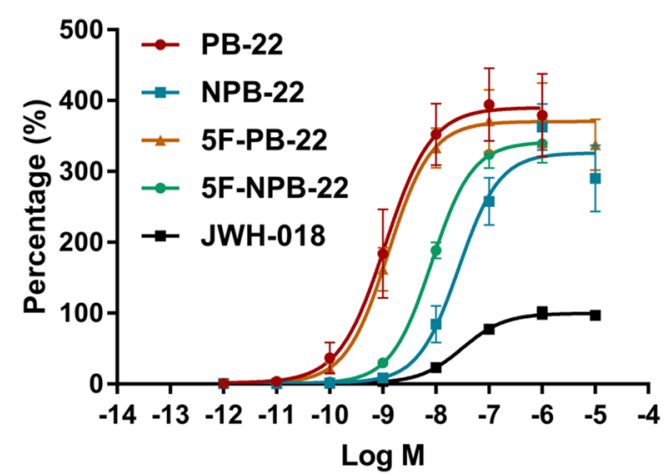

b $\quad \mathrm{CB}_{2}$ activation (relative to $\mathrm{JWH}-018$ )

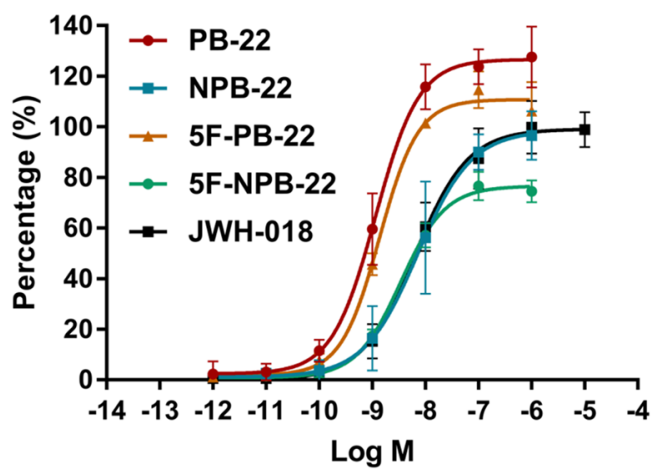

Fig. 9 Concentration-dependent response at $\mathrm{CB}_{1}(\mathbf{a})$ and $\mathrm{CB}_{2}(\mathbf{b})$ upon stimulation with different SCs. Data are given as mean receptor activation $(\%) \pm$ standard deviation (SD) $(n=5-8)$, normalised to the $E_{\max }$ of JWH-018

and 5F-PB-22 were in good correspondence with the previously reported result using the same reporter assays [43].

The ester hydrolysis products and ethyl esters were also evaluated at both CB receptors (except the 5F-PB-22 hydrolysis product as this was not available for analysis, but has previously been reported to have no activity at $\mathrm{CB}_{1}$ and $\mathrm{CB}_{2}$ [43]). At $\mathrm{CB}_{1}$ receptors, hydrolysis resulted in a strong reduction of the activity (to $<1 \%$ that of JWH-018) (Fig. 10a, exact values in supplementary material S5.2). The ethyl esters of PB-22 and 5F-PB-22 also showed a strongly 
Fig. 10 The maximal effect obtained at $\mathrm{CB}_{1}(\mathbf{a})$ and $\mathrm{CB}_{2}$ (b). Bars assigned with an asterisk are not significantly different from basal levels. Data are given as the mean percentage $\mathrm{CB}$ receptor activation (in comparison to the $E_{\max }$ of JWH018) $\pm \mathrm{SD}(n=5-8)$. EtOH ethanol a Maximal effect at $\mathrm{CB}_{1}$ (relative to the $\mathrm{E}_{\max }$ of JWH-018)

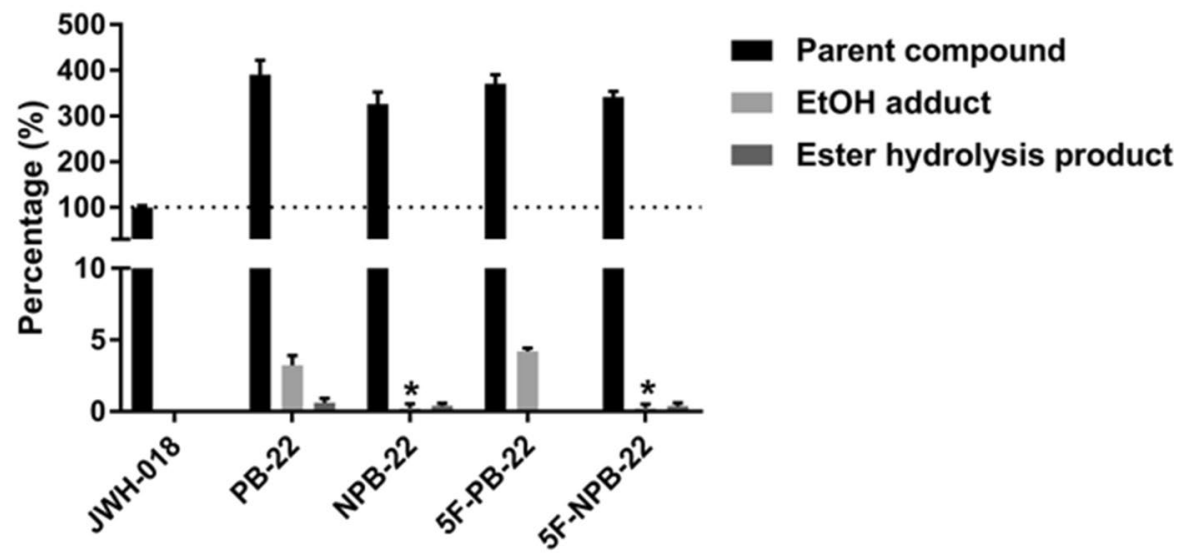

b Maximal effect at $\mathrm{CB}_{2}$ (relative to the $\mathrm{E}_{\max }$ of $\mathrm{JWH}-018$ )

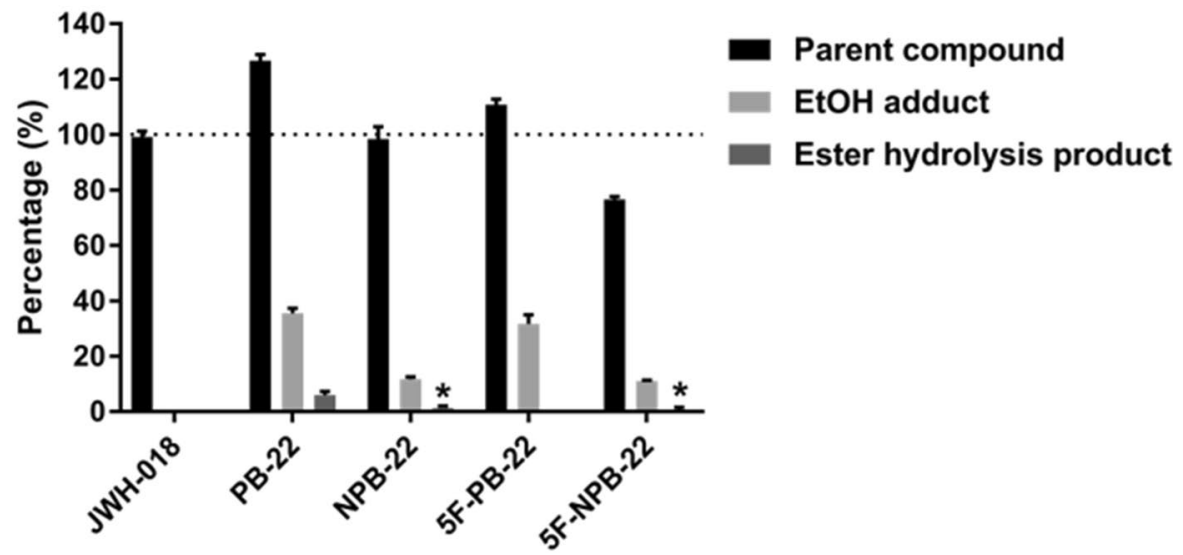

reduced $\mathrm{CB}_{1}$ activation (3.2 and $4.2 \%$ for the $\mathrm{PB}-22$ and 5F-PB-22 ethyl esters, respectively). No significant $\mathrm{CB}_{1}$ receptor activation was found for the indazole (NPB) derivatives. When compared with the $E_{\max }$ of the parent compounds, the relative activity of the ester hydrolysis products did not exceed $0.16 \%$, while that of the ethyl esters did not exceed $1.1 \%$.

With respect to $\mathrm{CB}_{2}$ activity, hydrolysis of the ester in the parent compound resulted in a strong reduction of the activity: only $6 \% \mathrm{CB}_{2}$ receptor activation for the ester hydrolysis product of PB-22 was found and an almost complete loss in $\mathrm{CB}_{2}$ receptor activation was found for the ester hydrolysis products of NPB-22 and 5F-NPB-22 (Fig. 10b, exact values in supplementary material S5.3). For PB-22, the ethyl esters resulted in a reduced $\mathrm{CB}_{2}$ activation compared to the parent compound, although still a $35.5 \% \mathrm{CB}_{2}$ receptor activation (relative to JWH-018) was found at high concentrations $(1 \mu \mathrm{M})$. The ethyl ester of 5F-PB-22 resulted in a $31.7 \%$ $\mathrm{CB}_{2}$ activation. For the ethyl esters of the NPB-derivatives, 11.7 and $11 \% \mathrm{CB}_{2}$ receptor activation was found. When compared to the $E_{\max }$ of the parent compounds, the activity of the ester hydrolysis products did not exceed $4.73 \%$, while that of the ethyl esters did not exceed $28.6 \%$. Because of the limited receptor activation at high concentrations, the contribution of these ethyl esters to the pharmacological profile of $\mathrm{SCs}$ is expected to be minimal. This is distinct from the $\mathrm{CB}_{1}$ and $\mathrm{CB}_{2}$ receptor activation by the hydroxyl-metabolites of (5F)-PB-22 (hydroxy-group on the pentyl side chain), where much higher activities ( $>100 \% E_{\max }$ JWH-018) were found [43].

\section{Conclusions}

Polydrug use is very common amongst illicit and recreational drug users. Here, we have shown in vitro evidence of the formation of SC-ethyl esters through an hCES-catalysed transesterification. Given that there are a number of reports which describe fatal and nonfatal cases in which toxicological findings are indicative of combined use of SCs and 
ethanol, it is suggested that clinical and forensic laboratories should monitor the potential appearance of the reported ethyl esters and/or their hydroxylated metabolites to facilitate interpretation of such cases. It is worth mentioning that detection of the described ethyl esters may be associated with several ester-containing SCs (common metabolites to a number of SCs); therefore, their detection should be accompanied by the concomitant presence of parent drugs (often difficult to be detected in urine) or appropriate metabolites that are unique to a certain SC to avoid any ambiguous reporting. The elimination profiles are needed to understand their potential contribution to toxicity in humans using SCs, especially if they prove to have a longer half-life than the parent compound. However, the ethics of administration of these unlicensed substances to humans makes this difficult, and the relevance of animal studies is questionable.

Acknowledgements We are grateful to TICTAC Communications for the provision of SC standards. The authors acknowledge the Royal Thai Government Scholarship for supporting this work. Annelies Cannaert and Christophe Stove acknowledge the support from Ghent UniversitySpecial Research Fund (BOF; PDO026-18 and BOF project Grants No. 01N00814 and 01J15517).

\section{Compliance with ethical standards}

Conflict of interest Paul Dargan is a member of the Scientific Committee of the European Monitoring Centre for Drugs and Drug Addiction and Chair of the Scientific Committee of the European Association of Poisons Control Centres and Clinical Toxicologists. All other authors have no conflict of interest to declare.

Ethical approval This article does not contain any studies with human participants or animals performed by any of the authors.

Open Access This article is distributed under the terms of the Creative Commons Attribution 4.0 International License (http://creativeco mmons.org/licenses/by/4.0/), which permits unrestricted use, distribution, and reproduction in any medium, provided you give appropriate credit to the original author(s) and the source, provide a link to the Creative Commons license, and indicate if changes were made.

\section{References}

1. EMCDDA (2018) European drug report 2018: trends and developments. Publications Office of the European Union, Luxembourg. https://doi.org/10.2810/800331

2. Tai S, Fantegrossi WE (2017) Pharmacological and toxicological effects of synthetic cannabinoids and their metabolites. Curr Top Behav Neurosci 32:249-262. https://doi. org/10.1007/7854_2016_60

3. Ralphs R, Williams L, Askew R, Norton A (2017) Adding spice to the porridge: the development of a synthetic cannabinoid market in an English prison. Int J Drug Policy 40:57-69. https://doi. org/10.1016/j.drugpo.2016.10.003

4. Dargan PI, Hudson S, Ramsey J, Wood DM (2011) The impact of changes in UK classification of the synthetic cannabinoid receptor agonists in 'Spice'. Int J Drug Policy 22:274-277. https://doi. org/10.1016/j.drugpo.2011.02.006

5. Smyth BP, Lyons S, Cullen W (2017) Decline in new psychoactive substance use disorders following legislation targeting headshops: evidence from national addiction treatment data. Drug Alcohol Rev 36:609-617. https://doi.org/10.1111/dar.12527

6. Webb NE, Wood DM, Greene SL, Hunter LJ, Archer JRH, Dines AM, Dargan PI (2019) Change in the new psychoactive substances associated with Emergency Department acute toxicity presentations associated with the introduction of the UK 2016 Psychoactive Substances Act. Clin Toxicol 57:36-41. https://doi. org/10.1080/15563650.2018.1494277

7. Blackman S, Bradley R (2017) From niche to stigma-headshops to prison: exploring the rise and fall of synthetic cannabinoid use among young adults. Int J Drug Policy 40:70-77. https://doi. org/10.1016/j.drugpo.2016.10.015

8. Waugh J, Najafi J, Hawkins L, Hill SL, Eddleston M, Vale JA, Thompson JP, Thomas SH (2016) Epidemiology and clinical features of toxicity following recreational use of synthetic cannabinoid receptor agonists: a report from the United Kingdom National Poisons Information Service. Clin Toxicol 54:512-518. https://doi.org/10.3109/15563650.2016.1171329

9. Cordeiro SK, Daro RC, Seung H, Klein-Schwartz W, Kim HK (2018) Evolution of clinical characteristics and outcomes of synthetic cannabinoid receptor agonist exposure in the United States: analysis of National Poison Data System data from 2010 to 2015. Addiction 113:1850-1861. https://doi.org/10.1111/add.14281

10. Presley BC, Gurney SM, Scott KS, Kacinko SL, Logan BK (2016) Metabolism and toxicological analysis of synthetic cannabinoids in biological fluids and tissues. Forensic Sci Rev 28:103-169 (PMID:27257717)

11. Abbate V, Schwenk M, Presley BC, Uchiyama N (2018) The ongoing challenge of novel psychoactive drugs of abuse. Part I. Synthetic cannabinoids (IUPAC Technical Report). Pure Appl Chem 90:1255-1282. https://doi.org/10.1515/pac-2017-0605

12. Brents LK, Reichard EE, Zimmerman SM, Moran JH, Fantegrossi WE, Prather PL (2011) Phase I hydroxylated metabolites of the K2 synthetic cannabinoid JWH-018 retain in vitro and in vivo cannabinoid 1 receptor affinity and activity. PLoS One 6:e21917. https://doi.org/10.1371/journal.pone.0021917

13. Chimalakonda KC, Seely KA, Bratton SM, Brents LK, Moran CL, Endres GW, James LP, Hollenberg PF, Prather PL, Radominska-Pandya A, Moran JH (2012) Cytochrome P450-mediated oxidative metabolism of abused synthetic cannabinoids found in K2/Spice: identification of novel cannabinoid receptor ligands. Drug Metab Dispos Biol Fate Chem 40:2174-2184. https://doi. org/10.1124/dmd.112.047530

14. Schoeder CT, Hess C, Madea B, Meiler J, Müller CE (2018) Pharmacological evaluation of new constituents of "Spice": synthetic cannabinoids based on indole, indazole, benzimidazole and carbazole scaffolds. Forensic Toxicol 36:385-403. https:// doi.org/10.1007/s11419-018-0415-Z

15. Kaizaki-Mitsumoto A, Hataoka K, Funada M, Odanaka Y, Kumamoto H, Numazawa S (2017) Pyrolysis of UR-144, a synthetic cannabinoid, augments an affinity to human $\mathrm{CB}_{1}$ receptor and cannabimimetic effects in mice. J Toxicol Sci 42:335-341. https ://doi.org/10.2131/jts.42.335

16. Raso S, Bell S (2017) Qualitative analysis and detection of the pyrolytic products of JWH-018 and 11 additional synthetic cannabinoids in the presence of common herbal smoking substrates. J Anal Toxicol 41:551-558. https://doi.org/10.1093/jat/bkx039

17. Thomas BF, Lefever TW, Cortes RA, Grabenauer M, Kovach AL, Cox AO, Patel PR, Pollard GT, Marusich JA, Kevin RC, Gamage TF, Wiley JL (2017) Thermolytic degradation of synthetic cannabinoids: chemical exposures and pharmacological 
consequences. J Pharmacol Exp Ther 361:162-171. https://doi. org/10.1124/jpet.116.238717

18. Kevin RC, Kovach AL, Lefever TW, Gamage TF, Wiley JL, McGregor IS, Thomas BF (2019) Toxic by design? Formation of thermal degradants and cyanide from carboxamide-type synthetic cannabinoids CUMYL-PICA, 5F-CUMYL-PICA, AMBFUBINACA, MDMB-FUBINACA, NNEI, and MN-18 during exposure to high temperatures. Forensic Toxicol 37:17-26. https ://doi.org/10.1007/s11419-018-0430-0

19. Menzies EL, Hudson SC, Dargan PI, Parkin MC, Wood DM, Kicman AT (2014) Characterizing metabolites and potential metabolic pathways for the novel psychoactive substance methoxetamine. Drug Test Anal 6:506-551. https://doi.org/10.1002/ dta. 1541

20. Diao X, Huestis MA (2017) Approaches, challenges, and advances in metabolism of new synthetic cannabinoids and identification of optimal urinary marker metabolites. Clin Pharmacol Ther 101:239-253. https://doi.org/10.1002/cpt.534

21. Hess C, Schoeder CT, Pillaiyar T, Madea B, Müller CE (2016) Pharmacological evaluation of synthetic cannabinoids identified as constituents of spice. Forensic Toxicol 34:329-343. https://doi. org/10.1007/s11419-016-0320-2

22. Floresta G, Apirakkan O, Rescifina A, Abbate V (2018) Discovery of high-affinity cannabinoid receptors ligands through a 3D-QSAR ushered by scaffold-hopping analysis. Molecules 23:e2183. https://doi.org/10.3390/molecules23092183

23. Liu Y, Williamson V, Setlow B, Cottler LB, Knackstedt LA (2018) The importance of considering polysubstance use: lessons from cocaine research. Drug Alcohol Depend 192:16-28. https://doi. org/10.1016/j.drugalcdep.2018.07.025

24. Kong TY, Kim JH, Kim DK, Lee HS (2018) Synthetic cannabinoids are substrates and inhibitors of multiple drug-metabolizing enzymes. Arch Pharm Res 41:691-710. https://doi.org/10.1007/ s12272-018-1055-X

25. Jatlow P (1993) Cocaethylene: pharmacologic activity and clinical significance. Ther Drug Monit 15:533-536 (PMID:8122289)

26. Laizure SC, Mandrell T, Gades NM, Parker RB (2003) Cocaethylene metabolism and interaction with cocaine and ethanol: role of carboxylesterases. Drug Metab Dispos 31:16-20. https://doi. org/10.1124/dmd.31.1.16

27. Patrick KS, Corbin TR, Murphy CE (2014) Ethylphenidate as a selective dopaminergic agonist and methylphenidate-ethanol transesterification biomarker. J Pharm Sci 103:3834-3842. https ://doi.org/10.1002/jps.24202

28. Tsujikawa K, Yamamuro T, Kuwayama K, Kanamori T, Iwata YT, Inoue H (2014) Thermal degradation of a new synthetic cannabinoid QUPIC during analysis by gas chromatography-mass spectrometry. Forensic Toxicol 32:201-207. https://doi.org/10.1007/ s11419-013-0221-6

29. UNODC (2019) Current NPS threats, vol 1. UNODC Laboratory and Scientific Section, Vienna

30. Behonick G, Shanks KG, Firchau DJ, Mathur G, Lynch CF, Nashelsky M, Jaskierny DJ, Meroueh C (2014) Four postmortem case reports with quantitative detection of the synthetic cannabinoid, 5F-PB-22. J Anal Toxicol 38:559-562. https://doi. org/10.1093/jat/bku048

31. Logan BK, Mohr ALA, Friscia M, Krotulski AJ, Papsun DM, Kacinko SL, Ropero-Miller JD, Huestis MA (2017) Reports of adverse events associated with use of novel psychoactive substances, 2013-2016: a review. J Anal Toxicol 41:573-610. https://doi.org/10.1093/jat/bkx031

32. Katz KD, Leonetti AL, Bailey BC, Surmaitis RM, Eustice ER, Kacinko S, Wheatley SM (2016) Case series of synthetic cannabinoid intoxication from one toxicology center. West J Emerg Med 17:290-294. https://doi.org/10.5811/westjem.2016.2.29519

33. Gieron J, Adamowicz P (2016) Fatal poisoning with the synthetic cannabinoid AB-CHMINACA and ethyl alcohol-a case study and literature review. Probl Forensic Sci 106:482-495

34. Angerer V, Jacobi S, Franz F, Auwärter V, Pietsch J (2017) Three fatalities associated with the synthetic cannabinoids 5F-ADB, 5F-PB-22, and AB-CHMINACA. Forensic Sci Int 281:e9-e15. https://doi.org/10.1016/j.forsciint.2017.10.042

35. Home Office (2018) Annual report on the Home Office Forensic Early Warning System (FEWS)-2015/16: a system to identify new psychoactive substances (NPS) in the UK. Information Policy Team, The National Archives, Kew, London

36. Cannaert A, Franz F, Auwärter V, Stove CP (2017) Activity-based detection of consumption of synthetic cannabinoids in authentic urine samples using a stable cannabinoid reporter system. Anal Chem 89:9527-9536. https://doi.org/10.1021/acs.analchem.7b025 52

37. Cannaert A, Storme J, Hess C, Auwärter V, Wille SMR, Stove CP (2018) Activity-based detection of cannabinoids in serum and plasma samples. Clin Chem 64:918-926. https://doi.org/10.1373/ clinchem.2017.285361

38. Cannaert A, Vandeputte M, Hudson S, Wood DM, Dargan PI, Stove CP (2019) Validation of activity-based screening for synthetic cannabinoid receptor agonists in a large set of serum samples. Clin Chem 65:347-349. https://doi.org/10.1373/clinc hem.2018.296905

39. Wohlfarth A, Gandhi AS, Pang S, Zhu M, Scheidweiler KB, Huestis MA (2014) Metabolism of synthetic cannabinoids PB-22 and its 5-fluoro analog, 5F-PB-22, by human hepatocyte incubation and high-resolution mass spectrometry. Anal Bioanal Chem 406:1763-1780. https://doi.org/10.1007/s00216-014-7668-0

40. Wang D, Zou L, Jin Q, Hou J, Ge G, Yang L (2018) Human carboxylesterases: a comprehensive review. Acta Pharm Sin B 8:699-712. https://doi.org/10.1016/j.apsb.2018.05.005

41. Laizure SC, Herring V, Hu Z, Witbrodt K, Parker RB (2013) The role of human carboxylesterases in drug metabolism: have we overlooked their importance? Pharmacotherapy 33:210-222. https ://doi.org/10.1002/phar.1194

42. Imai T, Taketani M, Shii M, Hosokawa M, Chiba K (2006) Substrate specificity of carboxylesterase isozymes and their contribution to hydrolase activity in human liver and small intestine. Drug Metab Dispos 34:1734-1741. https://doi.org/10.1124/ dmd.106.009381

43. Cannaert A, Storme J, Franz F, Auwärter V, Stove CP (2016) Detection and activity profiling of synthetic cannabinoids and their metabolites with a newly developed bioassay. Anal Chem 88:11476-11485. https://doi.org/10.1021/acs.analchem.6b02600

Publisher's Note Springer Nature remains neutral with regard to jurisdictional claims in published maps and institutional affiliations. 